\section{Tooth Discoloration Using Calcium Silicate-Based Cements For Simulated Revascularization in Vitro}

Rui Barbosa Marques Junior ${ }^{1} \mathbb{D}$, Kusai Baroudi ${ }^{1} \mathbb{D}$, Alison Flávio Campos dos

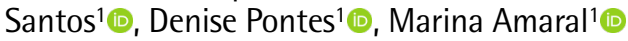

'Postgraduate Program in Dentistry, School of Dentistry, University of Taubaté, Taubaté, Brazil.

Correspondence: Marina Amaral, Rua dos Operarios, 09, Taubaté 12020-340, São Paulo, Brasil. Tel +55-12-3625-4149. e-mail: marinamaral_85@yahoo.com.br

\begin{abstract}
The endodontic revascularization may be an alternative treatment for necrotic immature teeth, however, several treatment steps may cause tooth discoloration. This study evaluated the use of three calcium silicate-based cements with different radiopacifying agents on the color alteration $(\Delta \mathrm{E})$ of extracted premolars after simulation of revascularization. Forty single rooted extracted premolars were shaped with \# 1-6 gates Glidden drills, rinsed with sodium hypochlorite, and filled with fresh human blood. Three calcium silicate-based cements with different radiopacifying agents (bismuth oxide - CSBi, calcium tungstate - CSW, and zirconium oxide - CSZr) were applied over the blood clot $(n=10)$. The control group received the application of a temporary zinc oxide-based cement (TFZn) $(n=10) . \Delta E$ was measured with a spectrophotometer, using the $L^{*} a^{*} b^{*}$ color system of the International Commission on Illumination (CIELab), in different times: prior to the preparation of the access cavity (t0); right after treatment ( $\mathrm{t} 1)$; and after one (t2), two (t3), three (t4) and four ( $\mathrm{t} 5$ ) months. The tooth site for color evaluation was standardized by silicon matrix, the color reading was performed 3 times per tooth, and the teeth were stored in $37^{\circ}$ water between evaluations. $\triangle E$, whiteness $\left(\mathrm{WI}_{\mathrm{D}}\right.$ index) and yellowness $\left(\mathrm{b}^{*}\right)$ were evaluated. Data were subjected to one-way ANOVA and repeated measures ANOVA, followed by Tukey's post hoc test $(\alpha=0.05)$. All groups were similar in $\Delta \mathrm{E} 1$ (t0-t1). The $\Delta \mathrm{E}$ was the lowest and constant in the control group. In all evaluation times, CSBi presented the highest $\Delta \mathrm{E}$ $(p<0.01)$. CSW and CSZr were similar in all evaluated times and presented intermediate $\Delta E$ values. $\mathrm{WI}_{\mathrm{D}}$ index from CSBi and CSW presented more distancing from 'white' reference. $\mathrm{CSBi}$ presented the greatest decrease in yellowness ( $b^{*}$ value). The cement containing bismuth oxide presented the highest color alteration values. All tested calcium silicatebased cements presented clinically perceptible discoloration. Calcium tungstate and zirconium oxide may be used as alternative radiopacifiers to decrease tooth discoloration after endodontic tooth revascularization.
\end{abstract}

Key Words: MTA, biodentine, tooth darkening.

\section{Introduction}

The pulp revascularization promotes deposition of dental hard tissue, resulting in strengthen of root walls and development of a normal apical morphology (apexification) in immature teeth which suffered necrosis during development (1). Pulp revascularization presents clinical success rates ranging from 86 (2) to 95\% (3) after 12 months. As a proposed protocol for tooth revascularization (4), after the diagnosis of teeth necrosis, the root canals and pulp chamber are cleaned (light instrumentation and irrigation with sodium hypochlorite) and receive a triple antibiotic paste. Two or three weeks later, the antibiotic paste is removed with sodium hypochlorite irrigation and an apical bleeding is induced inside the root canal (2), allowing the migration of cells which will promote root thickening and apical closure $(5,6)$. Finally, the cement (mineral trioxide aggregate) is placed on the blood clot in order to form a hermetic sealing, followed by a cotton ball and a temporary filling (4).
The Mineral Trioxide Aggregate (MTA) is the gold standard among biomaterials indicated for covering of exposed pulp tissue. It is also indicated as the material to be placed over the blood clot during tooth revascularization (4), promoting seal against the penetration of oral bacteria into the pulp space (7). The MTA produces calcium silicate hydrate and calcium hydroxide on hydration, which will be relevant for deposition of calcium phosphate on the cement surface (8). It also presents good results in cell viability and cell migration assays, promoting healing and mineralization activity (9). MTA presents a radiopacifying agent in its composition and the bismuth oxide was one of the firsts to be used, however, its destabilization is reported to cause tooth discoloration $(10,11)$.

For this reason, the addition of stabilizing substances, as aluminum fluoride (AIF3) (11) or alternative radiopacifying agents have been suggested. One possibility is the use of calcium tungstate because it does not present heavy metals in composition, avoiding tooth discoloration (according 
to manufacturer, MTA Repair HP, Angelus). Good results regarding tooth color alteration are reported in literature (12). The zirconium oxide also showed lower darkening potential compared to bismuth oxide (13).

The tooth color alteration is usually evaluated with a spectrophotometer (10). The color measurement is made in different evaluation times, and represented by the $L^{*} a^{*} b^{*}$ color system of the International Commission on Illumination (CIELab) (14). According to the CIELab, three parameters are measured: lightness ranging from black (0) to white $(100)\left(L^{*}\right)$; color ranging from green to red $\left(a^{*}\right)$; and color ranging from blue to yellow $\left(b^{*}\right)$. When the alteration of these parameters $(\Delta E)$ are superior to a determined valor, $\Delta \mathrm{E}$ can be classified as clinically perceptible (perceptibility threshold - PT) and clinically acceptable (acceptability threshold - AT) (15). Beside $\Delta \mathrm{E}$, parameters as whiteness and yellowness have been used to describe more specifically the color alteration in dental tissues $(16,17)$.

The aim of this study was to evaluate the discoloration of extracted premolars after the simulation of revascularization and the use of calcium silicate cements with three different radiopacifying agents: bismuth oxide, calcium tungstate and zirconium oxide. The tested hypothesis is that the cement with bismuth oxide in composition causes more tooth color alteration compared to other cements.

\section{Material and Methods}

The use of 40 single-rooted upper and lower premolars, extracted for orthodontic reasons, was approved by the Ethics Committee in Research of the University of Taubate (protocol \#71025817.5.0000.5501). Teeth were clinically and radiographically free of caries, cracks, restorations and pathological staining. Teeth were stored into 0.5\% chloramine immediately after extraction, cleaned and immersed in fresh $0.5 \%$ chloramine solution at $6^{\circ} \mathrm{C}$ until use. Teeth were consecutively numbered from 1 to 40 , and a simple draw was performed as a randomization process to allocate 10 teeth per group $(n=10$, determined according to literature $(12,18)$

Root sizes were standardized by sectioning $7 \mathrm{~mm}$ bellow cementoenamel junction with diamond bur (3215, KG Sorensen, Cotia, Brazil) in a high speed hand piece under water cooling, followed by polishing with prophylaxis paste (Herjos, Coltene, Rio de Janeiro, Brazil). The color was measured before preparation of the cavity access (to) as described: teeth were positioned into a silicon guide (Zetalabor, Zhermack, Badia Polesine, Italy) with a central circular opening in the same size of the spectrophotometer reading tip ( $3 \mathrm{~mm}$ radius, VITA Easyshade ${ }^{\circledR}$ Advance 4.0; Vita Zahnfabrik, Bad Sackingen, Germany). The tooth portion to be verified was defined as the central portion of the buccal tooth surface, $3 \mathrm{~mm}$ occlusal from the cementoenamel junction. A device was fabricated to hold the spectrophotometer and the silicon matrix-tooth always in the same position (19) (Fig. 1). Color evaluation was performed three times per tooth and the mean value was considered $(17,20)$. The evaluation was performed by the same operator, and the assembly (Fig. 1) ensured the reading at the same position. Spectrophotometer was calibrated before each measurement, according to manufacturer's instructions.

A conventional cavity access was prepared and the root canals were cleaned and shaped by \#1-6 Gates Glidden Drills (Dentsply Maillefer, Ballaigues, Switzerland) through all length (passing the apical foramen, for root canal size standardization) and rinsed with $2.5 \%$ sodium hypochlorite (Biodinâmica Química e Farmacêutica, lbiporã, Brazil) before and after each drill (total $25 \mathrm{ml}$ ). Thereafter, root canals were rinsed with $1 \mathrm{ml}$ 17\% EDTA (Biodinâmica Química e Farmacêutica), and again rinsed with $5 \mathrm{ml} 2.5 \%$ sodium hypochlorite (Biodinâmica Química e Farmacêutica). Root canals were rinsed with distilled water (4) and dried with \#80 absorbent paper points (Dentsply/Maillefer S.A.). Root apex was sealed with a self-etching adhesive (Single Bond Universal, 3M ESPE, St Paul, MN, EUA) and a $2 \mathrm{~mm}$-thick composite resin increment (color A2, Filtek ${ }^{\text {TM }}$ Z250, XT,
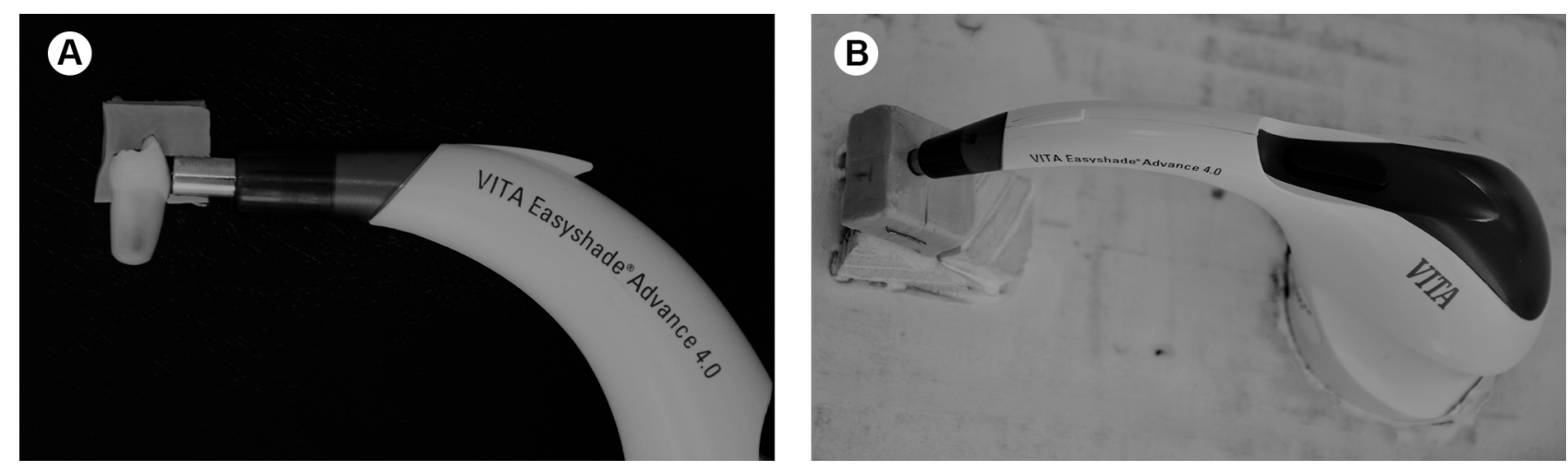

Figure 1. A - silicon guide for standard local of color measurement. B - assembly standardizing the position between sample to be read (positioned inside silicon matrix) and spectrophotometer. 
3M- ESPE). Both the adhesive and the composite resin were light activated for 20s (Bluephase, Ivoclar Vivadent, Schaan, Liechtentein).

For the simulation of revascularization process, fresh human blood was taken by a trained person from a single volunteer $(12 \mathrm{~mL})$ by venipuncture. Blood was collected into sterile tubes and immediately used for filling root canals. Root canals were filled with blood until the cementoenamel junction with syringe and needle (Navitip $30 \mathrm{G}$, Ultradent, South Jordan, UT, USA) under a clinical microscope (ALL 01, Alliance Microscopia, São Carlos, SP, Brazil). After 15 min (formation of blood clot) (21), three calcium silicate-based cements (Table 1) and the temporary filling were prepared according to manufacturers' instructions and inserted into the pulp chamber, on the blood clot with a thickness of 3 $\mathrm{mm}(\mathrm{n}=10)$. According to respective manufacturers, these cements are indicated for direct pulp-capping, except for the temporary filling (used as control).

The pulp chamber was cleaned with dentin excavator to remove cement from dentin walls, follow by rub of cotton ball with isopropyl alcohol. Tooth access cavity was sealed with a self-etching adhesive (Single Bond Universal, 3M ESPE) and a flowable composite resin (A2, Natural Flow, DFL, Taquara, Brazil). Both the adhesive and the resin cement were light activated for 20s (Bluephase, Ivoclar Vivadent).

The teeth were stored immersed into distilled water at $37^{\circ} \mathrm{C}$, during the evaluation time. Color verification was performed in the same device as mentioned before, prior to the preparation of the access cavity ( $\mathrm{t} 0$ ); immediately after simulation of revascularization and cement application (t1); and one (t2), two (t3), three (t4) and four (t5) months after simulation of revascularization and cement application. Polishing with prophylaxis paste was performed before each evaluation.

Color measurements were reported by the $L^{*} a^{*} b^{*}$ system, from the CIE (14). The color alteration $(\Delta \mathrm{E})$ was calculated between the different measurement times: t0-t1 $(\Delta \mathrm{E} 1) ; \mathrm{t0}-\mathrm{t} 2(\Delta \mathrm{E} 2) ; \mathrm{t0}-\mathrm{t} 3(\Delta \mathrm{E} 3) ; \mathrm{t0}-\mathrm{t} 4(\Delta \mathrm{E} 4) ; \mathrm{t0}-\mathrm{t} 5$ $(\Delta \mathrm{E})$, by the equation:

$$
\Delta E=\left[\left(\Delta L^{*}\right)^{2}+\left(\Delta a^{*}\right)^{2}+\left(\Delta b^{*}\right)^{2}\right]^{\frac{1}{2}}
$$

$\Delta \mathrm{E}$ is the color alteration,

$$
\begin{aligned}
\Delta L^{*} & =L^{*} 0-L^{*} 1 \\
\Delta a^{*} & =a^{*} 0-a^{*} 1 \\
\Delta b^{*} & =b^{*} 0-b^{*} 1
\end{aligned}
$$

Where " 0 " is the initial measurement and " 1 " is the value obtained in each measurement time.

The whiteness index $\left(W I_{D}\right)$ (16) was calculated as $W I_{D=} 0.511 L^{*}-2.24 a^{*}-1.100 b^{*}$. The obtained coefficients positively weight CIELab values close to reference white $\left(L^{*}=100, a^{*}=0, b^{*}=0\right)$. The yellowish was presented based in $b^{*}$ value (17).

The Kolmogorov-Smirnov test was applied for verification of the normal distribution. Groups were compared to each other in each evaluation time by oneway ANOVA followed by Tukey's post-hoc test; and each group was evaluated regarding $\Delta \mathrm{E}$ during time by repeated measure ANOVA at the significance level of $\alpha=0.05$.

\section{Results}

The material $(p<0.001)$ and the evaluation time $(\mathrm{p}<0.001)$ presented a significant influence in $\Delta \mathrm{E}$ of teeth after the simulation of revascularization process. Table 2 shows the results for the $\Delta \mathrm{E}$ analysis, and the statistical significance. In the first evaluation $(\Delta \mathrm{E} 1)$, all groups were similar to each other. In the other evaluation times $(\triangle E 2$, $\Delta \mathrm{E} 3, \Delta \mathrm{E} 4$, and $\Delta \mathrm{E} 5), \mathrm{CSBi}$ always presented the highest values of color alteration, while TFZn presented the lowest values. TFZn (control) group did not suffer additional color

\begin{tabular}{|c|c|c|c|}
\hline Group Labeling & Radiopacity angent & $\begin{array}{l}\text { Commertial brand } \\
\text { name; manufacturer }\end{array}$ & Composition* \\
\hline CSBi & $\begin{array}{l}\text { Bismuth oxide } \\
\text { (Bi203) }\end{array}$ & White MTA; Angelus & $\begin{array}{l}\text { Tricalcium silicate }(66.1 \%) \text {; Dicalcium silicate }(8.5 \%) ; \\
\text { Tricalcium aluminate }(2.0 \%) \text {; Tetracalciumaluminoferrite; } \\
\text { Calcium sulfate; Bismuth oxide (14\%); Calcium oxide(8\%); } \\
\text { Silicon oxide }(0.5 \%) \text {; Aluminium oxide }(1 \%)\end{array}$ \\
\hline CSW & $\begin{array}{l}\text { Calcium Tungstate } \\
\text { (W04Ca) }\end{array}$ & $\begin{array}{l}\text { MTA Repair } \\
\text { HP; Angelus }\end{array}$ & $\begin{array}{l}\text { Tricalcium silicate } 3 \mathrm{CaO} . \mathrm{SiO} 2 \text {; Dicalcium silicate } 2 \mathrm{CaO} \text {. } \\
\text { SiO2; Tricalcium aluminate } 3 \mathrm{CaO} . \mathrm{Al} 2 \mathrm{O} 3 \text {; } \\
\text { Calcium oxide } \mathrm{CaO} \text {; Calcium Tungstate } \mathrm{CaW04.}\end{array}$ \\
\hline CSZr & $\begin{array}{l}\text { Zirconium oxide } \\
\text { (ZrO2) }\end{array}$ & Biodentine; Septodont & $\begin{array}{l}\text { Tricalcium silicate (3CaO.SiO2) (80.1\%); Dicalcium silicate (2CaO. } \\
\text { SiO2); Calcium carbonate (CaCO2)(14.9\%; filler); Zirconium Oxide } \\
\text { (ZrO2) (5\%; radioopacifier); Iron oxide(colouring agent). }\end{array}$ \\
\hline TFZn & Zinc oxide (Zn0) & Coltosol; Coltene & $\begin{array}{l}\text { Zinc oxide; Zinc sulphate, Calcium sulfate, Polyvinyl } \\
\text { acetate, Menthol, Dibutyl phthalate. }\end{array}$ \\
\hline
\end{tabular}
alteration over evaluation time, but the other materials did (Table 2).

Table 1 . The cements used in the present study, respective commercial brand name, manufacturer and composition

*According to manufacturer. 
Figure 2 shows the variation in $\mathrm{WI}_{\mathrm{D}}$ (whiteness) index (the variation from the initial value should be observed for each material since initial values were not similar between groups). Values from CSBi and CSW presented the highest increase (which means a decrease in white color, or

Table 2. Color alteration and respective standard deviation of the tested groups according to different measurement times. $(\Delta \mathrm{E} 1$ : t0-t1; $\Delta \mathrm{E} 2$ : t0-t2; $\Delta \mathrm{E} 3$ : t0-t3; $\Delta \mathrm{E} 4: \mathrm{t} 0-\mathrm{t} 4 ; \Delta \mathrm{E} 5$ : t0-t5)

\begin{tabular}{lccccc}
\hline Tested groups & $\Delta \mathrm{E} 1^{*}$ & $\Delta \mathrm{E} 2^{*}$ & $\Delta \mathrm{E} 3^{*}$ & $\Delta \mathrm{E}^{*}$ & $\Delta \mathrm{E}^{*}$ \\
\hline CSBi & $\begin{array}{c}3.97 \\
(1.59) \mathrm{Aa}\end{array}$ & $\begin{array}{c}16.42 \\
(6.04)^{\mathrm{Cb}}\end{array}$ & $\begin{array}{c}20.03 \\
(6.25) \mathrm{Cb}\end{array}$ & $\begin{array}{c}22.03 \\
(6.95) \mathrm{Cb}\end{array}$ & $\begin{array}{c}22.49 \\
(7.12) \mathrm{Cb}\end{array}$ \\
& 4.64 & 10.66 & 12.71 & 14.86 & 15.17 \\
$\mathrm{CSW}$ & $(2.82) \mathrm{Aa}$ & $(4.81) \mathrm{Bab}$ & $(4.45) \mathrm{Bb}$ & $(6.29) \mathrm{Bb}$ & $(6.11) \mathrm{Bb}$ \\
& & & & & \\
& 3.43 & 10.27 & 11.14 & 11.98 & 12.39 \\
$\mathrm{CSZr}$ & $(1.92) \mathrm{Aa}$ & $(4.14) \mathrm{Bab}$ & $(4.20) \mathrm{Bb}$ & $(4.53) \mathrm{Bb}$ & $(4.39) \mathrm{Bb}$ \\
& & & & & \\
TFZn & 5.03 & 3.83 & 3.32 & 3.85 & 3.90 \\
& $(3.42) \mathrm{Aa}$ & $(1.43) \mathrm{Aa}$ & $(1.92) \mathrm{Aa}$ & $(1.70) \mathrm{Aa}$ & $(1.82) \mathrm{Aa}$ \\
$\mathrm{p}$-value & 0.513 & $<0.001$ & $<0.001$ & $<0.001$ & $<0.001$ \\
\hline
\end{tabular}

*Different uppercase letters indicate statistical difference in the same column. Different lowercase letters indicate statistical difference in the same line.

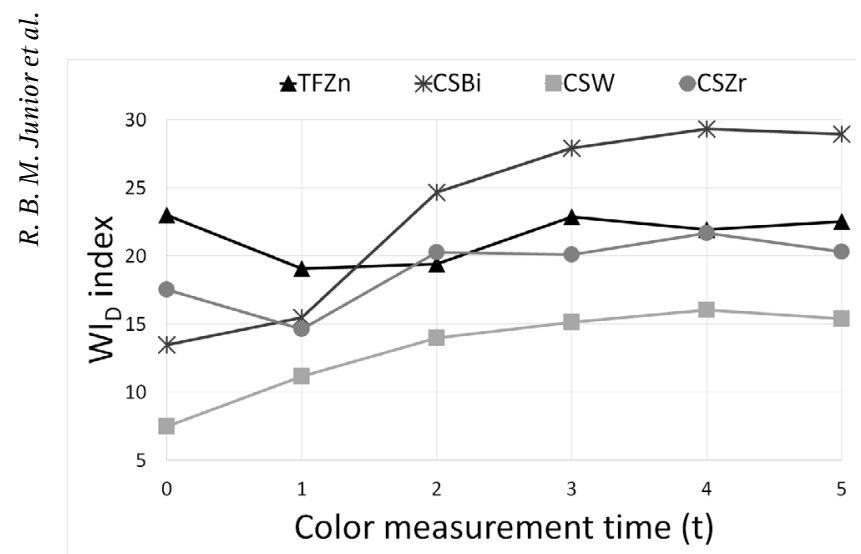

Figure $2 . \mathrm{WI}_{\mathrm{D}}$ (whiteness index) according to each material and the evaluation time (the increase in values indicates darkening).

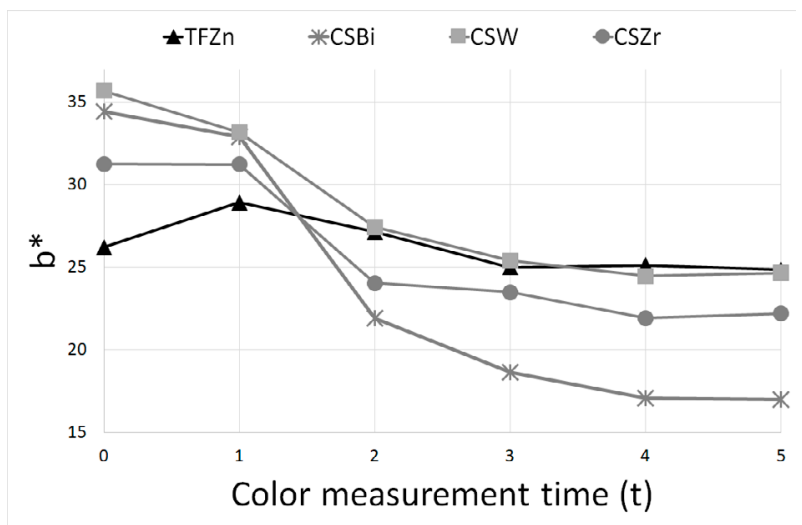

Figure 3. The $b^{*}$ value (yellowness characteristic) according to each material and the evaluation time (the decrease in values indicates that the color is changing from yellow to blue). darkening) compared to TFZn and CSZr. Figure 3 shows the variation in $b^{*}$ value. CSBi presented the greatest decrease in $b^{*}$ value (decrease in yellowness) where; TFZn was stable, and CSZr and CSW presented intermediate values (the variation from the initial value should be observed for each material, since initial values were not similar between groups).

\section{Discussion}

The silicate cement containing bismuth oxide caused the highest color alteration $(\Delta \mathrm{E})$ regarding to the evaluation time, accepting the tested hypothesis. Cements with alternative radiopacifiers also caused color alterations, but lower than bismuth oxide cement. On the other hand, the control (the cement without radiopacifier) caused a constant color alteration during the evaluation time. In the first evaluation period $(\Delta \mathrm{E} 1)$, all groups presented similar color alteration, which may be attributed to the revascularization process itself; specifically, the presence of the blood clot (22-24). The penetration of red blood cells into the tooth structure may cause color alteration $(23,25)$. The cement used as a control (TFZn) contains mainly zinc oxide in composition (Table 1). It is not indicated to be placed on the blood clot in the revascularization process; but it was used as a control in the present study since it has no tooth color alteration potential (10). Color alteration in the group TFZn was present since the first evaluation time $(\Delta \mathrm{E} 1)$ and kept a constant rate after 4 months ( $\Delta \mathrm{E} 5$, Table 2). Constant measurements over time in the control group reflect the constant measurements condition and the low risk of bias in this kind of study (13).

The silicate cement containing bismuth oxide as a radiopacifier (CSBi cement) presented the highest color alteration among the tested cements in all evaluation times after $\Delta \mathrm{E} 1$ (Table 2). These results are similar to other studies $(10,20,26)$. Literature attributes the tooth discoloration to the phase change in the bismuth oxide. The contact of bismuth oxide with oxidizing agents as sodium hypochlorite or amino acids present in dentin collagen leads to oxygen lose and formation of sodium chloride on the black precipitate. Then, bismuth is no longer existed in the oxide forms as it reacts, showing phase change and causing discoloration (27). Besides that, the similar color alteration in $\Delta \mathrm{E} 4$ and $\Delta \mathrm{E} 5$ may represent the maximum color alteration reached, where all presented bismuths are reacted and subsequent time would not result in even more color alteration, however, prolonged times of evaluation are necessary to confirm this hypothesis. CSBi also presented the highest alteration in $\mathrm{WI}_{D}$ index and $\mathrm{b}^{*}$ value. The increase in $W I_{D}$ index (Fig. 2) indicates the 'darkening' (distancing 
from white) of teeth over time. And the greatest decrease in $b^{*}$ value (Fig. 3) indicates a decrease in yellowness, tending for more 'blue' color on the tooth surface.

Silicate cements with alternative radiopacifiers such as, calcium tungstate (CSW) and zirconium oxide (CSZr) also presented color alteration, which was lower than CSBi cement, as reported in literature $(20,26)$ and yet, higher than the control cement (Table 2). Only the fact of bismuth oxide being absent of cements composition could explain the low color alteration presented by both materials (18). Also, the application of these cements may have exacerbated the tooth color alteration caused by the blood (21). Some studies reported the color alteration caused by the cements tested (CSW and CSZr) as not clinically noticeable (22).

In the $\mathrm{WI}_{\mathrm{D}}$ analysis (whiteness index), CSZr and TFZn presented stable results meaning that the white appearance of teeth did not change. But CSW and CSBi presented increasing in $\mathrm{WI}_{\mathrm{D}}$ values (Fig. 2) indicating that these groups became far from the 'white' reference (darkening). The $W_{D}$ index was developed based on CIELab system, and has proposed recently (17) as an alternative to the measurement and evaluation of whiteness. The evaluation in the variation of $b^{*}$ value, also based in the CIELab system, was validated as a parameter for yellowness perception (17), comparable to YIO and WIO indexes. The $b^{*}$ value is related to the perceptual yellowness of the tooth (17) and the coordinate varies from yellow $(+b)$ to blue $(-b)$ in the CELab system. By the $\Delta \mathrm{E}$ in CIELab system, it is not easy to relate the values to univariate perceptual clinical characteristics such as, whiteness and yellowness. Thus, additional parameters and indexes may be used to evaluate these characteristics individually (17).

Considering the perceptibility threshold and the acceptability threshold defined respectively as $\Delta \mathrm{E} a \mathrm{~b}=1.2$ and 2.7 (15), and the values showed in Table 2, all materials and evaluation times overcome the thresholds and would lead to unpleasant clinical color alteration. Stabilizers of bismuth oxide such as, zinc phosphate and aluminum fluoride have been investigated and showed good results regarding tooth color alteration $(10,11)$, making them promised alternatives as well. Furthermore, the sealing of pulp chamber with a dentin bonding agent may decrease color alteration, and yet it still does not prevent it (28).

The antibiotic paste used before bleeding inside the root canal was also shown to cause tooth discoloration (28) in the presence of residual sodium hypochlorite from root canal irrigation in contact to calcium silicate based cements (29). No simulation of these steps was performed in the present study, facilitating the isolation of the factor "radiopacifying agent" and its effect on tooth color alteration; however, it may represent a limitation in simulating the clinical situation. Also, the thickness of the mineralized tooth was not considered for groups' formation. The thickness of enamel and dentin may affect the color alteration caused by the blood and the materials used, since the materials were in contact with the internal dentin and color was measured in the enamel. Thus, thicker dentin/enamel structures may present lower color alteration $(30,31)$. This influence was partially neutralized by randomization of elements used.

Conclusions can be drawn that all cements tested in the present study for application after simulation of tooth revascularization presented clinically perceptible discoloration, as the simulated revascularization process itself. Furthermore, the calcium silicate-based cement containing bismuth oxide as a radiopacity agent presented the highest color alteration after 4 months. Alternative radiopacifiers such as, calcium tungstate and zirconium oxide promoted lower discoloration than bismuth oxide.

\section{Resumo}

A revascularização endodôntica pode ser um tratamento alternativo para dentes imaturos necrosados, porém, várias etapas do tratamento podem causar alteração de cor dental. Este estudo avaliou o uso de três cimentos a base de silicato de cálcio com diferentes agentes radiopacificadores na alteração de cor $(\Delta \mathrm{E})$ de pré-molares extraídos após a simulação de revascularização. Quarenta pré-molares unirradiculares extraidos foram conformados com brocas gates glidden \#1-6, irrigados com hipoclorito de sódio, e preenchidos com sangue humano fresco. Três cimentos a base de silicato de cálcio com diferentes agentes radiopacificadores (óxido de bismuto - CSBi, tungstato de cálcio - CSW, e óxido de zircônio - CSZr) foram aplicados sobre o coágulo sanguíneo $(n=10)$. 0 grupo controle recebeu a aplicação de um cimento temporário a base de óxido de zinco (TFZn) $(n=10) . \Delta E$ foi medida com um espectrofotômetro, utilizando o sistema de cor $\mathrm{L}^{*} \mathrm{a}^{*} \mathrm{~b}^{*}$ da International Commission on Illumination (CIELab), em tempos diferentes: previamente ao preparo da cavidade de acesso (t0); logo após o tratamento (t1); e após um (t2), dois (t3), três (t4) e quatro (t5) meses. 0 local do dente para a avaliação de cor foi padronizado por uma matriz de silicone, a leitura da cor foi realizada 3 vezes por dente, e os dentes foram armazenados em água a $37^{\circ} \mathrm{C}$ entre as avaliações. $\Delta \mathrm{E}$, 'clareamento' (indice $\mathrm{WI}_{\mathrm{D}}$ ) e tom amarelado $\left(\mathrm{b}^{*}\right)$ foram avaliados. 0 s dados foram submetidos ao teste de ANOVA um fator e teste ANOVA de medidas repetidas, seguidos pelo teste post hoc de Tukey $(\alpha=0,05)$. Todos os grupos foram semelhantes em $\Delta \mathrm{E} 1$ (t0-t1). A $\Delta \mathrm{E}$ foi menor e constante no grupo controle. Em todos os tempos de avaliação, CSBi apresentou os maiores valores de $\Delta E(p<0.01)$. CSW e CSZr foram semelhantes em todos os tempos avaliados e apresentaram valores intermediários de $\Delta \mathrm{E}$. 0 indice $\mathrm{WI}_{\mathrm{D}}$ de CSBi e CSW se distanciaram mais da referência 'branco'. CSBi apresentou maior diminuição no tom amarelado (valor de $b^{*}$ ) os outros grupos. 0 cimento contendo óxido de bismuto apresentou os maiores valores de alteração de cor. Todos os cimentos testados apresentaram alteração de cor clinicamente perceptível. 0 tungstato de cálcio e óxido de zircônio podem ser usados como radiopacificares alternativos para a diminuição da alteração de cor dental após o processo de revascularização endodontica.

\section{References}

1. He L, Zhong J, Gong Q, Kim SG, Zeichner SJ, Xiang L, et al. Treatment of necrotic teeth by apical revascularization: meta-analysis. Sci Rep 2017;7:13941.

2. Shivashankar VY, Johns DA, Maroli RK, Sekar M, Chandrasekaran $R$, Karthikeyan $\mathrm{S}$, et al. Comparison of the effect of PRP, PRF and induced bleeding in the revascularization of teeth with necrotic pulp and open apex: a triple blind randomized clinical trial. J Clin Diagn Res 2017;11:ZC34-ZC39.

3. Aly MM, Taha SEE, El Sayed MA, Youssef R, Omar HM. Clinical and 
radiographic evaluation of biodentine and mineral trioxide aggregate in revascularization of non-vital immature permanent anterior teeth (randomized clinical study). Int J Paediatr Dent 2019;29:464-473.

4. Namour M, Theys S. Pulp revascularization of immature permanent teeth: a review of the literature and a proposal of a new clinical protocol. ScientificWorldJournal 2014;2014:737503.

5. Huang GTJ. Apexification: The beginning of its end. Int Endod J. 2009;42:855-866.

6. Jeeruphan T, Jantarat J, Yanpiset K, Suwannapan L, Khewsawai $P$, Hargreaves KM. Mahidol study 1: comparison of radiographic and survival outcomes of immature teeth treated with either regenerative endodontic or apexification methods: a retrospective study. J Endod 2012;38:1330-1336.

7. Faizuddin U, Solomon RV, Mattapathi J, Guniganti SS. Revitalization of traumatized immature tooth with platelet-rich fibrin. Contemp Clin Dent 2015;6:574-576.

8. Camilleri J. Characterization and hydration kinetics of tricalcium silicate cement for use as a dental biomaterial. Dent Mater 2011;27:836-844.

9. Seo DG, Lee D, Kim YM, Song D, Kim SY. Biocompatibility and mineralization activity of three calcium silicate-based root canal sealers compared to conventional resin-based sealer in human dental pulp stem cells. Materials (Basel) 2019;12:2482.

10. Marciano MA, Camilleri J, Costa RM, Matsumoto MA, Guimarães BM, Duarte MAH. Zinc oxide inhibits dental discoloration caused by white mineral trioxide aggregate Angelus. J Endod 2017;43:1001-1007.

11. Marciano MA, Camilleri J, Lucateli RL, Costa RM, Matsumoto MA, Duarte MAH. Physical, chemical, and biological properties of white MTA with additions of AIF3. Clin Oral Investig 2019;23:33-41.

12. Aguiar BA, Frota LMA, Taguatinga DT, Vivan RR, Camilleri J, Duarte $\mathrm{MAH}$, et al. Influence of ultrasonic agitation on bond strength, marginal adaptation, and tooth discoloration provided by three coronary barrier endodontic materials. Clin Oral Investig 2019;23:4113-4122.

13. MoŻyńska J, Metlerski M, Lipski M, Nowicka A. Tooth discoloration induced by different calcium silicate-based cements: a systematic review of in vitro studies. J Endod 2017;43:1593-1601.

14. International Commission on Illumination. Recommendations on uniform color spaces, color-difference equations, psychometric color terms. Paris, France: Bureau Central de la CIE;1978:1913.

15. Paravina $R D$, Ghinea $R$, Herrera $U$, Bona $A D$, Igiel $C$, Linninger $M$, et al. Color difference thresholds in dentistry. J Esthet Restor Dent 2015;27:S1-S9.

16. Pérez $M$ del $M$, Ghinea R, Rivas MJ, Yebra A, lonescu AM, Paravina RD, et al. Development of a customized whiteness index for dentistry based on CIELAB color space. Dent Mater 2016;32:461-467.

17. Sullivan $C$, Pan $Q$, Westland $S$, Ellwood R. A yellowness index for use in dentistry. J Dent 2019;91:103244

18. Kohli MR, Yamaguchi M, Setzer FC, Karabucak B. Spectrophotometric analysis of coronal tooth discoloration induced by various bioceramic cements and other endodontic materials. J Endod 2015;41:1862-1866.

19. Krastl G, Allgayer N, Lenherr P, Filippi A, Taneja P, Weiger R. Tooth discoloration induced by endodontic materials: a literature review. Dent Traumatol 2013;29:2-7.

20. Shokouhinejad N, Nekoofar MH, Pirmoazen S, Shamshiri AR, Dummer PM. Evaluation and comparison of occurrence of tooth discoloration after the application of various calcium silicate-based cements: an ex vivo study. J Endod 2016;42:140-144.

21. Shokouhinejad N, Khoshkhounejad M, Alikhasi M, Bagheri P, Camilleri J. Prevention of coronal discoloration induced by regenerative endodontic treatment in an ex vivo model. Clin Oral Investig 2018;22:1725-1731.

22. Bortoluzzi EA, Araujo GS, Guerreiro Tanomaru JM, Tanomaru-Filho M. Marginal gingiva discoloration by gray MTA: a case report. J Endod 2007;33:325-327.

23. Felman D, Parashos P. Coronal tooth discoloration and white mineral trioxide aggregate. J Endod 2013;39:484-487.

24. Bonte $E$, Beslot $A$, Boukpessi T, Lasfargues JJ. MTA versus $\mathrm{Ca}(\mathrm{OH}) 2$ in apexification of non-vital immature permanent teeth: a randomized clinical trial comparison. Clin Oral Investig 2015;19:1381-1388.

25. Marin PD, Heithersay GS, Bridges TE. A quantitative comparison of traditional and non-peroxide bleaching agents. Endod Dent Traumatol 1998;14:64-67.

26. Kang SH, Shin YS, Lee HS, Kim SO, Shin Y, Jung IY, et al. Color changes of teeth after treatment with various mineral trioxide aggregate-based materials: an ex vivo study. J Endod 2015;41:737-741.

27. Camilleri J. Color stability of white mineral trioxide aggregate in contact with hypochlorite solution. J Endod 2014;40:436-440.

28. Shokouhinejad N, Khoshkhounejad M, Alikhasi M, Bagheri P, Camilleri J. Prevention of coronal discoloration induced by regenerative endodontic treatment in an ex vivo model. Clin Oral Investig 2018;22:1725-1731.

29. Keskin C, Demiryurek EO, Ozyurek T. Color stabilities of calcium silicatebased materials in contact with different irrigation solutions. J Endod 2015;41:409-411.

30. Kwon SR, Wertz PW. Review of the mechanism of tooth whitening. J Esthet Restor Dent 2015;27:240-257.

31. Públio JD, D'Arce MB, Catelan A, Ambrosano GMB, Aguiar FHB, Lovadino JR, et al. Influence of enamel thickness on bleaching efficacy: an in-depth color analysis. Open Dent J 2016;10:438-445.

Received August 12, 2020 Accepted September 28, 2020 